\title{
EFFECTS OF PARKING LOT LOCATION ON SIZE AND PHYSIOLOGY OF FOUR SOUTHWESTERN U.S. LANDSCAPE TREES
}

\author{
By Sarah B. Celestian and Chris A. Martin
}

\begin{abstract}
This study evaluated effects of two parking lot landscape locations on size and physiology of four regionally common landscape tree species. Tree size measurements were made during August 2001 and 2002 and tree gas exchange and leaf chlorophyll concentrations were measured during April and August 2002. Trees were mostly smaller and leaf gas exchange fluxes were lower for Australian bottle tree (Brachychiton populenus Schott \& Endl.), Arizona ash (Fraxinus velutina Torr.), and Chinese elm (Ulmus parvifolia Jacq.) located within narrow landscaped medians surrounded by asphalt compared with similarly aged trees in large landscaped areas along the parking lot perimeters. In contrast, parking lot location had no statistical effect on size of Argentine mesquite (Prosopis alba Griebach) except for diameter at breast height, which was significantly less for trees in the landscaped medians in 2002. Leaf chlorophyll concentrations of all trees located in landscaped medians were lower than those of trees within surrounding landscaped perimeter areas except for Australian bottle tree, which had higher significantly leaf chlorophyll concentration during April when located in landscaped medians. Based on these results, Argentine mesquite appears to be the best of these four tree species for use in commercial parking lot landscapes because its growth and physiological function were least affected by parking lot location.
\end{abstract}

Key Words. Asphalt; chlorophyll; commercial land use; photosynthesis; stomatal conductance; urban trees.

Parking lots are a common feature of commercial land uses dominated by paved surfaces such as asphalt and concrete. Trees in commercial parking lots provide shade, enhance landscape aesthetics, screen unwanted views and wind, control stormwater runoff, and improve local air quality through pollutant uptake and reducing evaporative hydrocarbon emissions from parked cars (Scott et al. 1999).

Though commercial parking lots are designed to accommodate maximum loads of traffic, many parking lot ordinances also specify a ratio of the amount of landscaped area per number of parking spaces (Beatty 1989). As a result, parking lot trees are usually clustered in small or narrow landscaped islands or medians surrounded by expansive asphalt surfaces, or are found in more expansive landscaped areas along the parking lot perimeter (McPherson 2001).

Parking lot trees must contend with a number of microenvironmental stresses that might adversely affect their growth, such as restricted rooting volumes; limited access to water and nutrients; and elevated rhizosphere and canopy air temperatures caused by intense sunlight and the absorptive, reradiant properties of the asphalt and concrete surfaces (Kjelgren and Clark 1992; Graves 1994; Kjelgren and Montague 1998; Celestian and Martin 2004). Continuous exposure of trees, especially those within parking lot landscaped medians, to these conditions might adversely impact tree performance by either direct injury of tissues or by indirect inhibition of physiological processes such as nitrogen and carbon assimilation.

Often landscape designers and planners select tree species for parking lot landscapes based on their potential form and aesthetic attributes without consideration of environmental tolerance. Though parking lot microenvironments can adversely impact tree performance (Grabosky and Gilman 2004), the magnitude of impact might be species specific. The objective of this research was to study performance of four common southwest landscape trees in response to parking lot growing location. Tree performance was evaluated by measurements of size, mortality, and seasonal patterns of leaf gas exchange and chlorophyll concentration as indicators of physiological status.

\section{METHODS}

A study was conducted in the metropolitan area of Phoenix, Arizona, to evaluate effects of two parking lot landscape locations on size and physiology of four regionally common landscape tree species. The four tree species studied were Australian bottle tree (Brachychiton populneus Schott $\&$ Endl.), Arizona ash (Fraxinus velutina Torr.), Argentine mesquite (Prosopis alba Griebach), and Chinese elm (Ulmus parvifolia Jacq.). The Phoenix metropolitan region is situated in the broad expanse of the Salt River Valley at the northeastern edge of the Sonoran Desert in the southwestern United States $\left(33^{\circ} \mathrm{N} 112^{\circ} \mathrm{W}\right)$. The climate of Phoenix is seasonally hot and arid. Summers are long, usually lasting from May through September. Summer daytime maximum temperatures regularly exceed $40^{\circ} \mathrm{C}\left(104^{\circ} \mathrm{F}\right)$. Mean annual rainfall and potential evapotranspiration are about 180 and 2,250 $\mathrm{mm}$ (7 and 89 in.), respectively. Because of the aridity, commercial landscapes in Phoenix require supplemental water that is normally provided on a regular and frequent 
basis throughout the year by electronically controlled drip and overhead sprinkler irrigation systems.

\section{Parking Lot Selection}

Commercial parking lots in the Phoenix metropolitan area with narrow landscaped medians surrounded by expansive areas of asphalt and large landscaped areas around the parking lot perimeter were screened to find those that were constructed between the years 1985 and 2000 and had landscape plantings with trees that were planted at the time of parking lot development. The following criteria were then used to ultimately select 11 commercial parking lots as sites for this study.

- At each parking lot, trees in landscape medians and perimeter areas must be apart of the original landscape planting at time of construction and established for more than 5 years.

- At least six trees of the same species must be present in both landscaped median and perimeter areas at each parking lot site.

- Trees must be more than $5 \mathrm{~m}(16 \mathrm{ft})$ apart from each other and $30 \mathrm{~m}(98 \mathrm{ft}$ ) from any building or covered parking area.

- Parking lots were not selected if trees were located under power lines or near any other aboveground obstruction that would result in an unnatural or managed deformation of canopy structure.

- All trees must have a single trunk.

- All trees must be regularly irrigated, show no symptoms of drought stress such as flaccid leaves or abnormal leaf drop, and be maintained by local landscape professionals.

Of the 11 parking lots selected for study, Australian bottle tree was located at one parking lot (Figure 1), Arizona ash at three parking lots, Argentine mesquite at three parking lots, and Chinese elm at four parking lots.

The landscaped medians at each parking lot ranged in size and shape, from small and rectangular, approximately $1.2 \times$ $5.3 \mathrm{~m}(4 \times 17 \mathrm{ft})$, to large, elongated strips approximately $1.2 \times 24.4 \mathrm{~m}(4 \times 80 \mathrm{ft})$ in length. In addition to trees, each landscaped median had a mixture of small, upright, and prostrate shrubs with decomposing granite as a landscape surface mulch and concrete curb edging, and was completely surrounded by asphalt surfaces for least $9 \mathrm{~m}$ (30 ft) away from the concrete curb edging. Trees within the landscaped

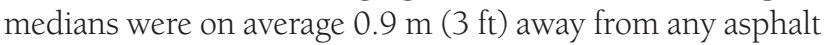
surface. The larger landscaped areas along the parking lot perimeters varied in size and shape but were at least $5 \mathrm{~m}$ (16 $\mathrm{ft}$ ) wide and over $20 \mathrm{~m}$ (66 ft) in length. Trees within the landscaped perimeter areas were on average $3 \mathrm{~m}(10 \mathrm{ft})$ away from an asphalt surface. The landscaped perimeter areas had surfaces covered with a mixture of decomposing granite mulch, small shrubs and ground covers, or turfgrass.

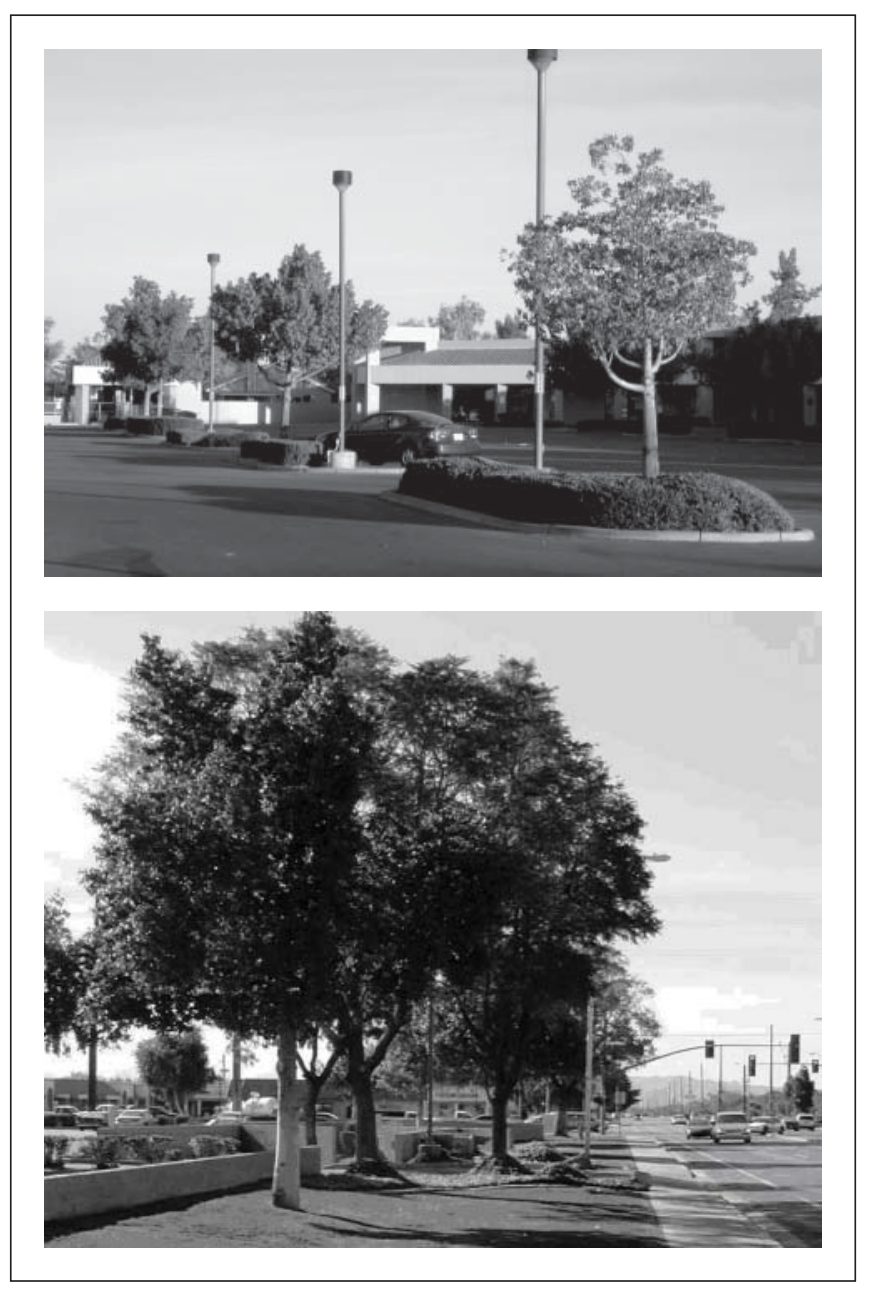

Figure 1. Australian bottle tree (Brachychiton populneus) in narrow parking lot landscape medians (top) and a landscape area at the perimeter (bottom) of a parking lot study site in Phoenix, Arizona. Digital images captured by S. Celestian, August 2002.

At each parking lot, one sample of rhizosphere soil [15 to $30 \mathrm{~cm}$ (6 to $12 \mathrm{in}$.) depth] was collected from under the canopy drip line on the north side of each tree at both the median and perimeter locations for analysis of soil chemical properties. Measurements of soil $\mathrm{pH}$ and electrical conductivity (EC) were made using the saturated paste method. Measurements of percentages of carbon and nitrogen were made using a CHN/O infrared gas analyzer. The ranges of values for all 11 parking lots were $\mathrm{pH} 7.5$ to 8.4 , EC 0.5 to $8.5 \mathrm{dS} / \mathrm{m}$, total nitrogen 0.1 to $1.8 \mathrm{mg} / \mathrm{g}$, and carbon 2.2 to $27.9 \mathrm{mg} / \mathrm{g}$

\section{Size}

For each tree, measurements of height, canopy diameter in two ordinations (north to south and east to west), and trunk diameter at breast height (dbh) were made during August 
2001 and 2002. Heights were measured with a clinometer at

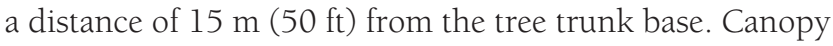
and trunk diameters were measured with a steel tape. Additionally, during August 2002, counts of mortality that had occurred during the two years of study were made.

\section{Physiology}

During April and August 2002, measurements of leaf gas exchange were made using a $1 / 4 \mathrm{~L}(1 / 2 \mathrm{pt})$ chamber attached to a portable photosynthesis system (LI 6200, LI-COR

Biosciences, Inc., Lincoln, NE). Gas exchange measurements were made on recently physiologically mature, sun-adapted leaves under seasonally clear and calm weather conditions from early morning ( $0700 \mathrm{hr}$ ) to late morning (1100 hr) on consecutive days following the protocol of Martin and Stabler (2002) as the expected times for maximum carbon assimilation by landscape trees in central Arizona for those times of year. Photosynthetically active radiation during the morning measurements ranged from 650 to $1940 \mu \mathrm{mol} / \mathrm{m}^{2} / \mathrm{s}$. At each parking lot, measurements were replicated on four widely distributed leaves of six trees per parking lot location (landscaped median and perimeter areas). Gas exchange of trees in only one parking lot was measured each day, and measurements of median and perimeter trees were alternated throughout the sample period each day.

Measurements of leaf chlorophyll concentration were also made for all trees during April and August 2002. For Australian bottle tree, Arizona ash, and Chinese elm, estimates of leaf chlorophyll levels were made by randomly sampling 28 fully expanded sun leaves per each of six trees per planting location using a SPAD 502 meter (Minolta Camera Co., Osaka, Japan). Actual chlorophyll concentrations were estimated from simple regression models of SPAD values to actual chlorophyll concentrations ( $R^{2}$ values ranged from 0.86 to 0.98 ) for each tree species using the chlorophyll extraction and determination method described by Arnon (1949). Use of the SPAD 502 meter was not possible for Argentine mesquite because it has finely divided, pinnately compound leaves. Instead, ten leaflets from ten fully expanded sun leaves per planting location were randomly harvested and chlorophyll was extracted and measured (Arnon 1949).

\section{Statistical Analysis}

A general linear model procedure (SAS version 6.03, SAS Institute, Cary, NC) was used to compare effects of parking lot location (median verses perimeter location as independent variables) on tree size (2001 and 2002) and physiological (April and August 2002) data. The data for each tree species were initially pooled for analysis of the effect of parking lot location on tree function. Subsequently, analyses of dependent variable responses to parking lot location were made separately for each tree species. Significance probabilities and $F$ ratios for location effects by species were generated by an analysis of variance (ANOVA) that were calculated using Type IV sums of squares (Milliken and Johnson 1984) because of an unequal number of dependent variable observations per independent treatment variable. For each tree species, treatment means for size by year and physiological function by time of year were separated statistically using Fisher's LSD test at $P \leq 0.05$.

\section{RESULTS \\ Size}

Generally, trees located within the landscaped medians were smaller than those located within landscaped areas along the parking lot perimeter, although the extent and significance of this difference was species specific (Table 1). Australian bottle trees in landscaped medians had significantly less dbh than those in perimeter landscaped areas both years. In 2002, height of bottle trees in landscaped medians was also significantly less than those in perimeter landscaped areas. Canopy diameters of bottle trees in both median and perimeter locations were statistically similar. Arizona ash and Chinese elm in landscaped medians had significantly less height, dbh, and canopy diameter than those in perimeter

Table 1. Effects of landscape median and perimeter planting locations in commercial parking lots on height, diameter at breast height (dbh), and canopy diameter of four landscape tree species in the Phoenix, Arizona, metropolitan area, in 2001 and 2002.

\begin{tabular}{|c|c|c|c|c|}
\hline \multirow[b]{2}{*}{ Landscape tree species } & \multicolumn{2}{|c|}{2001} & \multicolumn{2}{|c|}{2002} \\
\hline & Median & Perimeter & Median & Perimeter \\
\hline \multicolumn{5}{|l|}{ Australian bottle tree } \\
\hline Height (m) & $5.8^{z} \mathrm{a}^{y}$ & $7.1 \mathrm{a}$ & $6.2 \mathrm{~b}$ & $8.7 \mathrm{a}$ \\
\hline $\operatorname{Dbh}(\mathrm{cm})$ & $19.3 \mathrm{~b}$ & $27.4 \mathrm{a}$ & $19.7 \mathrm{~b}$ & $28.2 \mathrm{a}$ \\
\hline Canopy diameter (m) & $4.7 \mathrm{a}$ & $5.7 \mathrm{a}$ & $6.0 \mathrm{a}$ & $7.7 \mathrm{a}$ \\
\hline \multicolumn{5}{|l|}{ Arizona ash } \\
\hline Height (m) & $6.1 \mathrm{~b}$ & $8.9 \mathrm{a}$ & $6.3 \mathrm{~b}$ & $8.5 \mathrm{a}$ \\
\hline $\operatorname{Dbh}(\mathrm{cm})$ & $17.8 \mathrm{~b}$ & $30.6 \mathrm{a}$ & $18.0 \mathrm{~b}$ & $31.7 \mathrm{a}$ \\
\hline Canopy diameter (m) & $6.0 \mathrm{~b}$ & $9.4 \mathrm{a}$ & $6.0 \mathrm{~b}$ & $10.2 \mathrm{a}$ \\
\hline \multicolumn{5}{|l|}{ Argentine mesquite } \\
\hline Height $(\mathrm{m})$ & $6.1 \mathrm{a}$ & $6.9 \mathrm{a}$ & $6.5 \mathrm{a}$ & $8.0 \mathrm{a}$ \\
\hline $\operatorname{Dbh}(\mathrm{cm})$ & $15.8 \mathrm{a}$ & $19.7 \mathrm{a}$ & $16.7 \mathrm{~b}$ & $22.0 \mathrm{a}$ \\
\hline Canopy diameter (m) & $7.5 \mathrm{~b}$ & $9.2 \mathrm{a}$ & $8.7 \mathrm{a}$ & $9.7 \mathrm{a}$ \\
\hline \multicolumn{5}{|l|}{ Chinese elm } \\
\hline Height (m) & $4.7 \mathrm{~b}$ & $7.9 \mathrm{a}$ & $4.7 \mathrm{~b}$ & $7.9 \mathrm{a}$ \\
\hline $\operatorname{Dbh}(\mathrm{cm})$ & $10.8 \mathrm{~b}$ & $21.0 \mathrm{a}$ & $11.2 \mathrm{~b}$ & $21.2 \mathrm{a}$ \\
\hline Canopy diameter (m) & $5.3 \mathrm{~b}$ & $9.4 \mathrm{a}$ & $5.2 \mathrm{~b}$ & $9.1 \mathrm{a}$ \\
\hline
\end{tabular}

${ }^{2}$ Values are treatment means, for Australian bottle, tree $n=5$; for Arizona ash, $n=9$ perimeter or $n=10$ median; for Argentine mesquite, $n=10$; for Chinese elm, $n=27$ perimeter or $n=33$ median.

'Treatment means followed by the same letter within rows by year are not significantly different, Fisher's LSD test, $\alpha=0.05$. 
landscape beds both years. Argentine mesquite in landscaped medians had significantly less canopy diameter in 2001 and less dbh in 2002 than those in perimeter landscaped areas. Argentine mesquite height was not affected by parking lot location. During the study, two Argentine mesquite trees in the parking lot medians were removed because of wind damage caused by intense monsoon storms during summer 2001. Otherwise, no tree mortalities occurred.

\section{Physiology}

Australian bottle tree leaf net photosynthesis (A), stomatal conductance $\left(\mathrm{g}_{\mathrm{s}}\right)$, and chlorophyll concentration were affected by an interaction of time of year (April and August) and parking lot location (Table 2). In April, leaf A and $g_{s}$ of bottle trees in landscaped medians were about 36\% and $27 \%$, respectively, less than leaves of those in perimeter landscaped areas (Table 3). However in August, leaf A of perimeter trees was $9 \%$ greater than that of median trees, while leaf $g_{s}$ of median trees was not statistically different than that of perimeter trees. In April, leaf chlorophyll concentration of bottle trees within the landscaped medians was $9 \%$ greater than it was for trees within the perimeter areas. In August, however, this trend was reversed and leaf chlorophyll concentration of perimeter trees was 7\% greater than it was for trees within the landscaped medians. Parking lot location had no statistical effect on the ratio of internal leaf mesophyll to ambient air $\mathrm{CO}_{2}$ concentration in April than they were in August.

For Arizona ash, leaf $\mathrm{A}$ and $\mathrm{Ci} / \mathrm{Ca}$ were affected by an interaction of time of year and parking lot location (Table 2). Leaf $A$ of ash trees in the landscaped perimeter areas was not statistically different than that of median trees in April but was about $60 \%$ greater than that of median trees in August (Table 3). The $\mathrm{Ci} / \mathrm{Ca}$ of ash trees was not affected by parking lot location in April but was about 8\% greater than that of perimeter trees in August. Ash leaf $g_{s}$ and chlorophyll concentration were not affected by an interaction of time of year and planting location (Table 2). Leaf $g_{\mathrm{s}}$ and chlorophyll concentration were about 50\% and 20\% higher in August than April, respectively, and 35\% and 10\% higher for perimeter trees than median trees, respectively (Table 3).

For Argentine mesquite, only leaf chlorophyll concentration was affected by an interaction of time of year and parking lot location (Table 2). In April, leaf chlorophyll concentration of perimeter trees was about 30\% greater than it was for median trees, but was not affected by parking lot location in August (Table 3). Mesquite leaf A and $\mathrm{Ci} / \mathrm{Ca}$ were greatest in April, and $\mathrm{g}_{\mathrm{s}}$ was greatest in August. Mesquite leaf $\mathrm{A}, \mathrm{g}_{\mathrm{s}}$, and $\mathrm{Ci} / \mathrm{Ca}$ were not affected by parking lot location (Table 2).

For Chinese elm, leaf A, g, $\mathrm{gi} / \mathrm{Ca}$ and chlorophyll concentration were all affected by an interaction of time of $(\mathrm{Ci} / \mathrm{Ca})$ of bottle trees, though $\mathrm{Ci} / \mathrm{Ca}$ values were $11 \%$ higher

year and parking lot location (Table 2). Leaf A and chlorophyll concentration of perimeter trees were $6 \%$ and $14 \%$ greater, respectively, than that of median trees in April, but $21 \%$ and $25 \%$ greater, respectively, than that of median trees in August (Table 3). Leaf $\mathrm{g}_{\mathrm{s}}$ and $\mathrm{Ci} / \mathrm{Ca}$ of median trees were $9 \%$ and $4 \%$, greater, respectively, than perimeter trees in April. In contrast, leaf $\mathrm{g}_{\mathrm{s}}$ and $\mathrm{Ci} / \mathrm{Ca}$ of perimeter trees were $11 \%$ and $5 \%$ greater, respectively, than that of median trees in August.

\section{DISCUSSION}

Asphalt is the dominant surface component of commercial parking lots. Consequently, trees in commercial parking lot landscapes must contend with an array of environmental stress factors related to the thermophysical characteristics of asphalt paving and limited belowground growing space (Celestian and Martin 2004; Grabosky and Gilman 2004). After 2 years of study, we found that the size and physiological health of trees located in narrow landscaped medians surrounded by asphalt paving tended to be less than for

Table 2. Significance probabilities and $F$ ratio generated by an analysis of variance (ANOVA) of the effects of commercial parking lot planting location (landscape median and perimeter) and time of year (April and August 2002) on leaf gas exchange [net carbon assimilation (A), stomatal conductance $\left(\mathrm{g}_{\mathrm{s}}\right)$, internal leaf to ambient $\mathrm{CO}_{2}$ concentration $\left.(\mathrm{Ci} / \mathrm{Ca})\right]$ and leaf chlorophyll concentration $(\mathrm{Chl})$ of four landscape tree species in Phoenix, Arizona.

\begin{tabular}{lllll}
\hline Tree species/ANOVA & $\mathrm{A}$ & $\mathrm{g}_{\mathrm{s}}$ & $\mathrm{Ci} / \mathrm{Ca}$ & $\mathrm{Chl}$ \\
\hline $\begin{array}{l}\text { Australian bottle tree } \\
\text { Location }\end{array}$ & 0.0001 & 0.0147 & 0.3238 & 0.0001 \\
Time of year & 0.0001 & 0.0001 & 0.0092 & 0.0001 \\
Location $\times$ time & 0.0001 & 0.0001 & 0.1639 & 0.0001 \\
F ratio & 23.45 & 17.48 & 12.09 & 7.41 \\
& & & & \\
Arizona ash & & & & \\
Location & 0.0001 & 0.0001 & 0.0001 & 0.0001 \\
Time of year & 0.2433 & 0.0001 & 0.0001 & 0.0001 \\
Location $\times$ time & 0.0191 & 0.1012 & 0.0001 & 0.3351 \\
F ratio & 18.88 & 52.15 & 177.78 & 11.92 \\
& & & & \\
Argentine mesquite & & & & \\
Location & 0.0930 & 0.0614 & 0.1910 & 0.0001 \\
Time of year & 0.0041 & 0.0001 & 0.0001 & 0.4340 \\
Location $\times$ time & 0.2367 & 0.0652 & 0.1638 & 0.0077 \\
F ratio & 10.45 & 9.96 & 97.88 & 2.96 \\
& & & & \\
Chinese elm & & & & \\
Location & 0.0009 & 0.8806 & 0.0561 & 0.0001 \\
Time of year & 0.0001 & 0.8776 & 0.0001 & 0.0001 \\
& & & & \\
Location $\times$ time & 0.0061 & 0.0004 & 0.0002 & 0.0008 \\
F ratio & 9.81 & 6.15 & 16.26 & 9.39 \\
\hline & & & & \\
\hline
\end{tabular}


Table 3. Effect of commercial parking lot planting location (landscape median and perimeter) and time of year (April and August 2002) on leaf carbon assimilation (A), stomatal conductance $\left(\mathrm{g}_{\mathrm{s}}\right)$, internal leaf to ambient $\mathrm{CO}_{2}$ concentrations $(\mathrm{Ci} / \mathrm{Ca})$, and leaf chlorophyll concentration $(\mathrm{Chl})$ of four landscape tree species in Phoenix, Arizona.

\begin{tabular}{|c|c|c|c|c|c|c|c|c|}
\hline \multirow{2}{*}{$\begin{array}{l}\text { Tree species/ } \\
\text { Parking lot location } \\
\end{array}$} & \multicolumn{2}{|c|}{$\mathrm{A}\left(\mathrm{mol} / \mathrm{m}^{2} / \mathrm{s}\right)$} & \multicolumn{2}{|c|}{$\mathrm{g}_{\mathrm{s}}\left(\mu \mathrm{mol} / \mathrm{m}^{2} / \mathrm{s}\right)$} & \multicolumn{2}{|c|}{$\mathrm{Ci} / \mathrm{Ca}$} & \multicolumn{2}{|c|}{ Chl (mg/g) } \\
\hline & Apr & Aug & Apr & Aug & Apr & Aug & Apr & Aug \\
\hline \multicolumn{9}{|l|}{ Australian bottle tree } \\
\hline Median & $6.0^{z} b^{y}$ & $5.7 \mathrm{~b}$ & $82.1 \mathrm{~b}$ & $64.7 \mathrm{a}$ & $0.60 \mathrm{a}$ & $0.55 \mathrm{a}$ & $5.6 \mathrm{a}$ & $4.0 \mathrm{~b}$ \\
\hline Perimeter & $9.5 \mathrm{a}$ & $6.2 \mathrm{a}$ & $112.5 \mathrm{a}$ & $59.5 \mathrm{a}$ & $0.58 \mathrm{a}$ & $0.50 \mathrm{a}$ & $5.1 \mathrm{~b}$ & $4.3 \mathrm{a}$ \\
\hline \multicolumn{9}{|l|}{ Arizona ash } \\
\hline Median & $9.2 \mathrm{a}$ & $7.4 \mathrm{~b}$ & $117.0 \mathrm{~b}$ & $178.0 \mathrm{~b}$ & $0.58 \mathrm{a}$ & $0.76 \mathrm{a}$ & $4.2 \mathrm{~b}$ & $4.3 \mathrm{~b}$ \\
\hline Perimeter & $11.6 \mathrm{a}$ & $12.2 \mathrm{a}$ & $156.9 \mathrm{a}$ & $241.6 \mathrm{a}$ & $0.58 \mathrm{a}$ & $0.70 \mathrm{~b}$ & $4.6 \mathrm{a}$ & $4.7 \mathrm{a}$ \\
\hline \multicolumn{9}{|l|}{ Argentine mesquite } \\
\hline Median & $7.9 \mathrm{a}$ & $5.3 \mathrm{a}$ & $73.6 \mathrm{a}$ & $85.6 \mathrm{a}$ & $0.46 \mathrm{a}$ & $0.67 \mathrm{a}$ & $3.6 \mathrm{~b}$ & $4.5 \mathrm{a}$ \\
\hline Perimeter & $8.2 \mathrm{a}$ & $6.5 \mathrm{a}$ & $75.9 \mathrm{a}$ & $103.6 \mathrm{a}$ & $0.47 \mathrm{a}$ & $0.66 \mathrm{a}$ & $5.4 \mathrm{a}$ & $4.7 \mathrm{a}$ \\
\hline \multicolumn{9}{|l|}{ Chinese elm } \\
\hline Median & $6.7 \mathrm{a}$ & $8.6 \mathrm{~b}$ & $121.2 \mathrm{~b}$ & $110.0 \mathrm{a}$ & $0.66 \mathrm{~b}$ & $0.57 \mathrm{a}$ & $3.6 \mathrm{~b}$ & $4.0 \mathrm{~b}$ \\
\hline Perimeter & $7.1 \mathrm{a}$ & $10.9 \mathrm{a}$ & $110.2 \mathrm{a}$ & $123.9 \mathrm{~b}$ & $0.69 \mathrm{a}$ & $0.54 b$ & $4.2 \mathrm{a}$ & $5.0 \mathrm{a}$ \\
\hline
\end{tabular}

${ }^{2}$ Values are treatment means. For gas exchange variables; $n=24$. For chlorophyll concentration, $n=168$, except for Argentine mesquite, $n=10$.

'Treatment means followed by the same letter within columns by tree species are not significantly different, Fisher's LSD test, $\alpha=0.05$.

trees in landscaped areas along the parking lot perimeter but that the magnitude of these effects was species specific. Since all trees at each parking lot site were regularly irrigated, any inhibitions of tree size and physiological function caused by parking lot median planting location was not likely due to a lack of available soil water.

Specific tree responses to Phoenix parking lot microenvironments may have been related to patterns of tree growth and habit. The evergreen Australian bottle tree has a largely indeterministic habit of growth in the southwest United States throughout the warmer months of the year, usually beginning in early spring. Data from Table 3 show that the physiological function of bottle trees in commercial parking lots was sensitive to the intense summer heat of Phoenix and that narrow landscaped medians further impaired physiological function manifested by reductions in leaf $\mathrm{A}, \mathrm{g}_{\mathrm{s}}$ and chlorophyll concentration compared to the bottle trees in surrounding landscape perimeter areas. These photosynthetic inhibitions may have been caused in part by the relative instability of chlorophyll at high temperature (Martin et al. 1995) and/or stomatal regulation of water loss (Mott 1988) and become a likely explanation for why height and dbh of bottle trees in landscaped medians was about 30\% less than for those in surrounding perimeter landscape beds.

Arizona ash and Chinese elm are two winter deciduous trees with deterministic growth habits. Both tree species are commonly used as shade trees in Phoenix urban landscapes. For Arizona ash, an upland canyon riparian tree from the southwestern United States, height, dbh, and canopy diameter of trees in landscaped medians was about 30\%, $42 \%$, and $20 \%$, respectively, less than for those in surrounding perimeter landscaped areas. These reductions in size may have been caused in part by concomitant reductions in carbon and nitrogen assimilation as evidenced in Table 3. Reduced leaf A, $g_{s}$, and chlorophyll concentrations for Arizona ash may have been caused in part by stomatal regulation of water loss, the relative instability of chlorophyll at high temperature, and the effect of supraoptimal rhizosphere temperatures on nitrogen uptake and/or root respiration (Foster et al. 1991; Ruter and Ingram 1991; Adam et al. 2003; Celestian and Martin 2004).

Of the four landscape trees studied, the size of Chinese elm was most adversely impacted by landscape median placement. Height, dbh, and canopy diameter of Chinese elm in landscaped medians were found to be about $60 \%$, $52 \%$, and $57 \%$, respectively, less than for those trees in surrounding perimeter landscape beds. These reductions in Chinese elm size were accompanied by inhibitions of physiological function. Although A and chlorophyll levels of the more physiological mature leaves in August were higher than that of the relatively immature leaves in April, leaf A and chlorophyll levels of trees within the landscaped medians were significantly less than for trees within the landscaped perimeter areas (Table 3). Moreover, median trees had greater leaf $g_{s}$ than perimeter trees in April but lower $g_{s}$ than perimeter trees in August. Supraoptimal root zone temperatures above $40^{\circ} \mathrm{C}\left(104^{\circ} \mathrm{F}\right)$ around the landscaped medians in summer (Celestian and Martin 2004) might have in part caused these inhibitions in physiological function for trees in the landscaped medians. In support of this hypothesis, previous research has shown that elevated root zone temperatures above $40^{\circ} \mathrm{C}\left(104^{\circ} \mathrm{F}\right)$ can inhibit leaf photosynthesis and conductance of Chinese elm (Martin et al. 1989). 
Size and physiology of Argentine mesquite, a partially deciduous tree from arid regions of south central South America, was the least affected by parking lot location. Overall, parking lot location had no significant effect on mesquite gas exchange. Otherwise, mesquite leaf A was lowest in August, while leaf $\mathrm{g}_{\mathrm{s}}$ and $\mathrm{Ci} / \mathrm{Ca}$ were lowest in April. Though Argentine mesquite trees in the landscaped medians in April had lower leaf chlorophyll levels than did trees in the landscaped perimeter areas, this did not appear to have any significant negative effect on carbon assimilation. As a result, the comparative size reduction of Argentine mesquite height and dbh between the two parking lot locations was only $15 \%$ and $22 \%$, respectively.

Arborists and landscape professionals normally prune trees in commercial parking lots to prevent tree obstruction of vehicles by raising the crown base height. This type of pruning activity might inadvertently reduce tree canopy diameter. Therefore, relative comparisons of dbh may be a better indicator than canopy diameter for evaluating the suitability of different tree species for use as shade or ornamental trees in commercial parking lot medians, even though many municipalities have ordinances that stipulate $50 \%$ shading coverage of total paved area within 15 years after development (Maco and McPherson 2002).

\section{CONCLUSION}

These data suggests that Argentine mesquite is the superior of the four landscape trees studied for use in commercial parking lot landscapes in the desert southwest, because size and physiological function were least affected by parking lot location. Landscape designers and planners in cities of the desert southwest should consider the use of Argentine mesquite in commercial parking lot landscapes because these trees were able to maintain relatively larger size and an aesthetically pleasing appearance even when planted in narrow landscaped medians surrounded by asphalt surfaces. Conversely, we recommend landscape designers and planners limit use of Arizona ash, Australian bottle tree, and Chinese elm in commercial parking lots to only larger landscaped perimeter areas because the performance of these tree species was more adversely affected by location in narrow landscaped medians asphalt than mesquite.

\section{LITERATURE CITED}

Adam, M.L., J.M. Kelly, W.R. Graves, and P. Dixon. 2003. Net nitrate uptake by Acer rubrum is a function of root-zone temperature. J. Plant Nutr. 26:202-222.

Arnon, D.I. 1949. Copper enzymes in isolated chloroplasts. Polyphenoloxidae in Beta vulgaris. Plant Physiol. 24:1-15.

Beatty, R.A. 1989. Planting guidelines for heat island mitigation and energy conservation, pp. 333-344. In
Garbesi, K., H. Akbari, and P. Martien (Eds.). Controlling Summer Heat Islands. Lawrence Berkeley Laboratory, Berkeley, CA.

Celestian, S.B., and C.A. Martin. 2004. Rhizosphere, surface, and air temperature patterns at parking lots in Phoenix, Arizona. J. Arboric. 30:245-251.

Foster, W.J., D.L. Ingram, and T.A. Nell. 1991.

Photosynthesis and root respiration in Ilex crenata 'Rotundifolia' at supraoptimal root-zone temperatures. HortScience 26:535-537.

Grabosky, J., and E. Gilman. 2004. Measurement and prediction of tree growth reduction from tree planting space design in established parking lots. J. Arboric. 30:154-164.

Graves, W.R. 1994. Urban root-zone temperatures and their potential impact on trees. J. Arboric. 20:24-27.

Kjelgren, R., and J.R. Clark. 1992. Microclimates and tree growth in three urban spaces. J. Environ. Hortic. 10:139-145.

Kjelgren, R., and T. Montague.1998. Urban tree transpiration over turf and asphalt surfaces. Atmos. Environ. 32:35-41.

Maco, S.E., and E.G. McPherson. 2002. Assessing canopy cover over streets and sidewalks in street tree populations. J. Arboric. 28:270-276.

Martin, C.A., and L.B. Stabler. 2002. Plant gas exchange and water status in urban desert landscapes. J. Arid Environ. 51:235-254.

Martin, C.A., D.L. Ingram, and T.A. Nell. 1989. Supraoptimal root-zone temperature alters growth and photosynthesis of holly and elm. J. Arboric. 15:272-276.

Martin C.A., J.C. Stutz, B.A. Kimball, S.B. Idso, and D.H. Akey. 1995. Growth and topological changes of Citrus limon (L.) Burm. f. 'Eureka' in response to high temperatures and elevated atmospheric $\mathrm{CO}_{2}$. J. Am. Soc. Hortic. Sci. 120:1025-1031.

McPherson, E.G. 2001. Sacramento's parking lot shading ordinance: environmental and economic costs of compliance. Landsc. Urban Plann. 57:105-123.

Milliken, G.A., and D.E. Johnson. 1984. Analysis of Messy Data, Vol. 1: Designed Experiments. Chapman and Hall, New York, NY. 473 pp.

Mott, K.A. 1988. Do stomata respond to $\mathrm{CO}_{2}$ concentrations other than intracellular? Plant Physiol. 86:200-203.

Ruter, J.M., and D.L. Ingram. 1991. Root respiration characteristics of 'Rotundifolia' holly under supraoptimal temperatures. J. Am. Soc. Hortic. Sci. 116:560-564.

Scott, K.I., J.R. Simpson, and E.G. McPherson. 1999. Effects of tree cover on parking lot microclimate and vehicle emissions. J. Arboric. 25:129-142. 
Acknowledgments. This research was funded in part by the TREE Fund John $\mathrm{Z}$. Duling Grant Program and by the National Science Foundation grant no. DEB-9714833

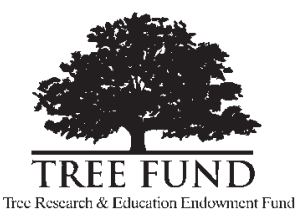

*Urban Horticultural Ecology Research Group

Department of Applied Biological Sciences

Arizona State University East

7001 E. Williams Field Rd.

Mesa, AZ 85212, U.S.

*Corresponding author:Chris A. Martin (chris.martin@asu.edu).

Résumé. Cette étude a évalué les effets de deux types d'environnement de stationnement par rapport à la dimension et la physiologie de quatre espèces d'arbres communément utilisées en aménagement dans la région. Les mesures de dimension des arbres ont été faites en août 2001 et août 2002, et les mesures en échange gazeux et de concentrations en chlorophylle ont été faites en avril 2002 et août 2002. Les arbres étaient pour la plupart plus petits et les flux d'échange foliaire gazeux étaient plus faibles chez le Brachychiton populneus, le Fraxinus velutina et l'Ulmus parvifolia lorsqu'ils étaient localisés dans des terre-pleins aménagés étroits entourés d'asphalte, et ce par rapport à ceux d'âge similaire dans des grands espaces aménagés en périphérie du stationnement. Au contraire, la localisation au sein du stationnement n'avait aucun effet statistique sur le Prosopis alba, sauf en ce qui regarde le diamètre au DHP qui était significativement moindre en 2002 dans le cas des arbres localisés en terre-plein. Les concentrations en chlorophylle pour tous les arbres localisés en terre-plein étaient plus faibles que pour les arbres au sein de zones aménagées en périphérie du stationnement, et ce à l'exception du Brachychiton populneus qui avait une concentration en chlorophylle foliaire significativement plus élevée en avril 2002 lorsqu'il était localisé en terre-plein. En se basant sur ces résultats, le Prosopis alba semble être la meilleure de ces quatre espèces à être utilisée au sein d'aménagements dans un stationnement commercial parce que sa croissance et ses fonctions physiologiques semblent moins affectées selon la localisation au sein du stationnement.
Zusammenfassung. Diese Studie bewertet den Effekt von zwei Parkplatzstandorten auf die Größe und Physiologie von 4 ortstypischen Baumarten. Im August 2001 und 2002 wurden die Baumgrößen gemessen und der Gasaustausch und die Blattchorophyllkonzentrationen wurden im April und August 2002 bestimmt. In kleinen schmalen Baumscheiben mit Asphalt umgeben waren die Baumgrößen und der Gasaustausch bei (Brachychiton populneus), (Fraxinus velutina) und (Ulmus parvifolia) niedriger als bei gleichaltrigen Bäumen in größeren Pflanzflächen. Im Kontrast dazu hatte die Größe der Baumscheibe keinen statistischen Effekt auf die Größe von (Prosopis alba) außer bei dem Brusthöhendurchmesser, welcher im Jahr 2002 bei den kleinen Flächen deutlich weniger betrug. Die Blattchorophyllkonzentrationen war bei allen Bäumen in den kleinen Flächen geringer mit Ausnahme bei den (Brachychiton populneus), welche eine deutlich höhere Blattchorophyllkonzentrationen im April aufwiesen. Basierend auf diesen Ergebnissen erwies sich der (Brachychiton populneus) von allen 4 Arten als bestgeeignet für den Einsatz bei der Bepflanzung von Parkplätzen, weil sein Wachstum und seine physiologischen am wenigsten durch die Standorte beeinflusst wurden.

Resumen. Este estudio evaluó los efectos en tamaño y fisiología de cuatro especies comunes de árboles para dos paisajes en lotes de estacionamientos. Las mediciones del tamaño de los árboles fueron hechas durante Agosto de 2001 y 2002 y las concentraciones de clorofila e intercambio de gases fueron medidas durante Abril y Agosto de 2002. Los árboles fueron más pequeños y los flujos de intercambio de gases foliares resultaron menores para el árbol 'botella' australiano (Brachychiton populneus), el fresno de Arizona (Fraxinus velutina) y el olmo chino (Ulmus parvifolia), localizados en lugares centrales con espacios estrechos rodeados por asfalto, comparados con árboles de edades similares localizados en grandes áreas perimetrales de los estacionamientos. En contraste, las localidades no tuvieron efecto estadístico sobre el mezquite argentino (Prosopis alba), excepto para los diámetros a la altura del pecho, los cuales fueron significativamente menores para los árboles en paisajes centrales en 2002. Las concentraciones de clorofila de todos los árboles localizados en lugares centrales fueron menores que los árboles circundantes perimetrales excepto para el árbol australiano, el cual tuvo concentraciones de clorofila significativamente más altas durante Abril, cuando se localizaron en paisajes centrales. Con base en estos resultados, el mezquite argentino parece ser la mejor de las cuatro especies para uso comercial en lotes de aparcadero, debido a que su crecimiento y su función fisiológica estuvieron menos afectados por la localización. 